\title{
Meta
}

Journal des traducteurs

Translators' Journal

\section{Translating Against the Grain: The Case of an Oriya Adaptation of Charles Dickens's A Tale of Two Cities}

\section{Jatindra K. Nayak et Himansu S. Mohapatra}

Volume 42, numéro 2, juin 1997

Lexicologie et terminologie II (1) et Traduction et post-colonialisme en Inde

Translation and Postcolonialism: India (2)

URI : https://id.erudit.org/iderudit/003697ar

DOI : https://doi.org/10.7202/003697ar

Aller au sommaire du numéro

Éditeur(s)

Les Presses de l'Université de Montréal

ISSN

0026-0452 (imprimé)

1492-1421 (numérique)

Découvrir la revue

Citer cet article

Nayak, J. K. \& Mohapatra, H. S. (1997). Translating Against the Grain: The Case of an Oriya Adaptation of Charles Dickens's A Tale of Two Cities. Meta, 42(2),

416-422. https://doi.org/10.7202/003697ar
Résumé de l'article

Dans un contexte de colonisation, la traduction est, en général, envisagée du point de vue du colonisateur. Il arrive cependant que le colonisé soit non pas l'objet, mais l'artisan de la traduction. L'adaptation de Godavarish Mishra du roman de Dicken A Tale of Two Cities en est une parfaite illustration. Ainsi, Mishra restitue le roman dans la culture cible, s'éloignant des thèmes dominants, allant jusqu'à rendre anti-colonial un texte résolument impérialiste. 


\title{
TRANSLATING AGAINST THE GRAIN: THE CASE OF AN ORIYA ADAPTATION OF CHARLES DICKENS'S A TALE OF TWO CITIES
}

\author{
JATINDRA K. NAYAK AND HIMANSU S. MOHAPATRA
}

Utkal University, Bhubaneswar, India

\begin{abstract}
Résumé
Dans un contexte de colonisation, la traduction est, en général, envisagée du point de vue du colonisateur. Il arrive cependant que le colonisé soit non pas l'objet, mais l'artisan de la traduction. L'adaptation de Godavarish Mishra du roman de Dicken A Tale of Two Cities en est une parfaite illustration. Ainsi, Mishra restitue le roman dans la culture cible, s'éloignant des thèmes dominants, allant jusqu'à rendre anti-colonial un texte résolument impérialiste.
\end{abstract}

\begin{abstract}
Most often the use of translation in the context of colonization is considered from the point of view of the colonizers. It is, however, possible for the colonized to be the subjects translating rather than mere objects of translation. One such case is the adaptation of Charles Dickens's A Tale of Two Cities by Godavarish Mishra. In the process of rewriting the novel, Mishra grounds it firmly in the target culture, even working against the dominant themes of the original novel, transforming the imperial text into an anti-colonial narrative.
\end{abstract}

It is true, as Eric Cheyfitz has argued, that the central act of European colonization was, and still is, the act of translation. This is probably nowhere more clearly in evidence than in colonial India, where translation was the colonizing discourse par excellence. The colonial administrators and educators devoted a large part of their time to producing translations of Indian texts. Translation was for them a means of appropriation of the resources of the colonized culture. It was a way of exercising control over an alien, and often resisting culture. In this sense translation functioned as the "mask of conquest," to put it in Gauri Viswanathan's fruitful phrase. It was an ideology that buttressed the political and economic domination of India by the British.

This is, of course, not the whole truth about translation, especially in the context of what has been called colonial transactions. The point is that the colonized culture also engages in translation even as it gets translated. In other words, it seeks to resist and subvert the culture of the colonizer by a process of strategic reoccupation of the spaces and discourses which are in the control of the dominating culture.

In the Indian context, too, translational activity was not confined to the British colonizers. It was something to which the articulate members of the colonized culture also staked their claim and their own terms. They engaged in translation, adaptation and rewriting of the canonical Western texts on a large scale as if in response to the exploitation of their own heritage by the colonizing power. They subscribed to a different politics of translation, a politics that can be described as "assimilative or subversive" as Harish Trivedi (1993 : 20) calls it.

Following Trivedi we might say that this was their way of coping with orientalism. If they were relentlessly orientalized by the British, they, in their turn, set out to occidentalize 
the latter. A fine instance of such occidentalism can be seen in the classic Oriya novel of social realism, Chha Mana Atha Guntha (Six Acres and Thirty-Two Decimals) produced by Fakir Mohan Senapati. In the famous trial chapter of the novel the narrator describes the ludicrous proceedings, conducted entirely in English, at the Cuttack sessions court. But before so doing the narrator slips in an irreverent remark to the effect that he has to take recourse to "translation" (tarzama) in order to be able to inform the reader of what transpired in the court room. We thus get an insight into the fact that the English judge is more interested in writing a letter to his Mem Sahib in London than in trying the case in hand. As a matter of fact, to counter Anglo-centrism we have to attend to such "choice examples of our own occidentalism," as Trivedi has finely put it. In the present paper we seek to foreground another such case as exemplified by Godavarish Mishra's reworking of Charles Dickens's A Tale of Two Cities (1859) into Athara Sa Satara (Eighteen Hundred Seventeen), a novel composed in the 1940s and published sometime between 1946 and 1951. Though not a canonical Oriya novel, this is, interestingly enough, an adaptation/ translation of the canonical Dickens novel. ${ }^{1}$ The case of this particular adaptation is extremely important, as we shall seek to demonstrate in the present paper. But a word before this about the complimentarity of translation and adaptation.

Without entering into a rigourous theoretical debate on the issue, we would like to observe that the activities designated by translation and adaptation are cognate with each other. They fall into the very broad spectrum of rewriting, which, as Vanamala Viswanatha and Sherry Simon (1996: xii) have rightly said, is rife in the Indian situation. To cite them, "Rewriting is a familiar and substantial part of the Indian literary tradition. there is a long history of transmission through rewriting. [...] It is productive to think of translation as falling into the broad range of practices which involve intertextual writing." Now adaptation is one species of "intertextual writing," and is thus related to translation. Also it is important to remember that the distinction between translation and adaptation was not made in many cultures, where the generic term translation served for a whole range of rewriting which included both activities. The reverse was also true in certain historical contexts, where translation was subsumed under adaptation. As Richard Jaquemond (1992:141) has pointed out, the Egyptian translations of French narratives in the colonial period "consisted most frequently in a very free transposition of the French narrative and actually was not called "translation" (tarjama), but "adaptation" (iqtibas), "arabization" (tar'ib), or even "egyptianization" (tamsir).

To return to Mishra's adaptive/translational project - we might now with confidence say that it was an expression of his cultural independence from the West. He was interested in the denaturalization rather in the naturalization of the foreign literary production. Thus Mishra's rewriting of Dickens's A Tale of Two Cities assumes significance because of the way in which it enables the colonized subject to appropriate the techniques and conventions of the text, belonging to the hegemonic mode, in order to effect a break with the dominant practice itself. In this sense Mishra's adaptive project might be said to differ from the merely culturalist project of one of his illustrious predecessors and shapers of modern Oriya poetry, Radhanath Ray, who borrowed freely from Western sources and produced parallel texts in Oriya. ${ }^{2}$ Mishra's is a politically and ideologically charged project, shot through with its author's anti-colonial, anti-English stance. The following article will seek to demonstrate the subversive character of this Oriya adaptation of A Tale of Two Cities at a particular historical moment, marked by the Indian people's struggle for freedom from colonial rule.

That Mishra's adaptation/translation of A Tale of Two Cities involves a process of reading Dickens's novel against the grain, is established from the author's choice of the title of the Oriya novel. By calling it "Athara Sa Satara" (Eighteen Seventeen) Mishra 
frees his novel from the sense of timelessness and fancifulness attaching to its English counterpart. For the word "tale" in Dickens's title is peculiarly odd and inapt given the text's claim to engage with the revolutionary upsurge of 1789 in France. It serves to divert attention from the historicity of the event. Mishra's novel, however, with its manifestly stark title of "Athara Sa Satara," foregrounds historicity. The title of the novel, which refers to the year in which an uprising against the British was organized by the dispossessed Oriya militia known as Paika in Khurda, a kingdom in the central part of the province of Orissa, holds the clue to the text's specifying, historicizing operation. Dickens speaks of particulars such as dates, but thinks them through in terms of universals such as individual psychology. Dickens's proneness towards individual psychologizing manifests itself early in the novel when the narrator moves suddenly away from a historically specific description of pre-Revolutionary France to meditate on the essential mystery and inscrutability of the human individual. Consider, for instance, this key-note striking passage which opens chapter 3 of Book I: "A wonderful fact to reflect upon, that every human creature is constituted to be that profound secret and mystery to every other. [...] that every one of those darkly clustered houses encloses its own secret; [...] that every beating heart in the hundreds and thousands of breasts there, is, in some of its imaginings, a secret to the heart nearest it" (p. 10)! Such an isolationist perspective naturally leads to the valorisation of the self-enclosed individual. Lucie Mannette, the idealized Dickensian heroine, feels apprehensive about "the echoes of all the footsteps that are coming by and by into our lives" (Book II, Ch. 5: 111). As John Gross has very aptly remarked, "Footsteps suggest other people, and in A Tale of Two Cities other people are primarily a threat and a source of danger" (1962: 189). Mishra's rewriting of the title does away with this universalizing tendency, even as it boldly sets out to portray the little known uprising of 1817 as a cataclysmic event of Orissan history for which the French Revolution of 1789 furnishes the most appropriate trope.

The rewriting of the title, of course, goes along with a rewriting of the central concerns as presented in Dickens's novel. The French Revolution of 1789, with which $A$ Tale of Two Cities, deals was an anti-feudal, anti-aristocratic revolution. The uprising of 1817, which occupies Mishra's attention in Athara Sa Satara, was an anti-British uprising on the part of the dispossessed Oriya militia with professedly feudal sympathies. No two movements are, therefore, more unlike one another than the revolution of 1789 and the uprising of 1817. If Mishra has rewritten seventeen eighty-nine as eighteen seventeen, it is because this act of rewriting, involving as it does an anti-colonial, anti-British agenda, is powerful enough to call forth an aggressive and audacious programme of "Oriyanization" of the canonical master text of Dickens.

In a sense Mishra has followed his chosen model closely by setting up an elaborate system of parallelisms and correspondences between his novel and that of Dickens. Thus the two cities of Paris and London are "translated" into the kingdoms of Khurda and Badamba. Ganapati and Ghanashyama appear before the reader as the Oriya version of Darnay and Carton. Mishra, in fact, throws the Dickensian theme of the double into sharper relief by giving his alike-looking heroes almost alike-sounding names. He also creates counterparts of other crucial features of $A$ Tale of Two Cities, as can be seen from his positing of Purunagada (Old Fort) and Jajar Singh Chati Ghara (The Chaultry of Jajar Singh), to name only a few, as the Oriya equivalents of the Bastille and the wine shop of the Defarges.

Mishra's programme of radical "Oriyanization," however, seems to cut much deeper than this principle of equivalencing might suggest. As a matter of fact, there is a deliberate breaking of this principle of equivalencing at the level of character creation and the overall vision of the narrative. Reference has already been made to the incongruity of Dickens's 
title. This incongruity is only a part of the larger incongruity of having to strip the novel of any real historical character. This is indeed something of a paradox in a novel supposedly based on historical sources about the French Revolution and might be taken as representing the shifting attitude to the genre of the historical novel in the middle of the nineteenth century in England, a shift brought about by the growing autonomization of the sphere of fictionality. This autonomization, of course, went hand in hand with the insulation of Victorian fiction from history, leading, as Sanders has remarked, to the "provincial fictional treatment of subjects derived from incidents in the French Revolution or the Norman Conquest" $(1978: 10)$. It is no wonder, therefore, that in the Victorian novels dealing with the historical process there was a marked decline from the great tradition set by Scott. As if to make amends for this lack of historical sense in the original text, Mishra introduces into his narrative a whole host of real actors of history such as Buxi Jagabandhu, the leader and the organizer of the uprising, who interact with the imaginary characters, thereby helping in the crystallization of a sense of history. This weaving of the narrative around the pivotal real actors of history serves a twofold purpose: firstly, to suggest that the lives of individual characters, their private destinies, are of less consequence than the fate of a whole struggling community or nation, and, secondly, to celebrate the leaders of this little known uprising by conferring on them the status of heroes. It is clear that the latter project is undertaken as part of a pressing and urgent political agenda of countering British historiography, which had systematically misrepresented these heroes as petty leaders of lost causes. It might also have suggested to Mishra an alternative conception of fiction as a form of interventionary praxis, which is so different from the imperial notion of fiction as, to use Edward Said's illuminating words, "antiseptically quarantined" (1993: xv) from history.

It would be in order now to analyse the vision of the two novels in question. Coming to A Tale of Two Cities first, it is to be noticed that its vision is dominated by love rather than by the dynamics of revolution. This is borne out, among other things, by what may be called a key-note striking passage in the novel: "Now, from the days when it was always summer in Eden, to these days when it is mostly winter in fallen latitudes, the world of a man has invariably gone one way - Charles Darnay's way - the way of the love of a woman" (p. 142). As a matter of fact, it is a novel where the love interest predominates. What Dickens seems to be doing in this novel about the revolution is no different from what he is always inclined to do. And this is to set up a small fictional world of inherently good individuals, living their private lives (in A Tale of Two Cities this world is that of Lucie, her father, Jarvis Lorry and Miss Pross) against a public social world which is corrupt and exploitative. No wonder then that, with such an ahistorical counterweight to the merely contingent phenomenon of history, the novel fails to integrate the revolutionary logic or dialectic into the texture of individual lives. The dominant strain of the novel is provided by "the love of a woman" and a woman's love for a man. The idea of the interplay of the personal and social, briefly envisioned in the conceptualization of revolution in the early part of the novel as a structure in the making, around which the "selves" of the French bourgeoisie were "closing in" (p. 206), is all but negated by this positing of an insulated private and domestic space as the space proper for the novel's few good characters.

The vision of Athara Sa Satara is, of course, radically different. History constitutes its essence and substance, as has been remarked earlier. No character in this novel, be it imaginary like Ganapati or historical like Buxi Jagabandhu, is allowed to escape into a private space outside the immediate and all pervasive historical context of the British colonization of Orissa. Even Ganapati, Darnay's counterpart in the novel, is pressed into the historical project of the anti-colonial struggle instead of being allowed to gallop away to 
safety and Kanchanbala, the counterpart of Lucie Mannette. What is most striking about the novel's vision is, however, this: although it writes of a defeated uprising unlike A Tale of Two Cities, its dominant mood is sanguine instead of pessimistic and defeatist. This only goes to show that the text of the Oriya novel does not despair of history in the way in which the text of the English novel tends to do. On the contrary, it goes on to conceive of the defeated uprising only as a temporary setback in the long march of the community towards victory. These words of the defeated but defiant leader Buxi Jagabandhu testify to the essentially optimistic outlook of the novelist: "We will secretly start the work of nation building. [...] Many years will pass like this. A day will come at last, maybe a hundred years later in the year 1917. [...] The new shapers of Khurda's destiny will appear on the stage of history then. And then a new life will animate all these towns and villages, these hills and forests, these meadows and fields" (pp. 664-665) (Translation ours). A comparison between Buxi Jagabandhu's "dialogical" final speech of exhortation in Athara Sa Satara and Sidney Carton's "monological" final vision of bliss brings out the essentially static and undialectical quality of a transformation process which has been rid of all active human agency of change. Here is the whole of Carton's vision, which may be contrasted with Buxi's speech, given in the text of this article: "I see Barsad, and Cly, Defarge, The Vengeance, the Juryman, the Judge, long ranks of the new oppressors who have risen on the destruction of the old, perishing by this retributive instrument, before it shall cease out of its present use. I see a beautiful city and a brilliant people rising from this abyss, and, in their struggles to be truly free, in their triumphs and defeats, through long years to come, I see the evil of this time and of the previous time of which this is the natural birth, gradually making expiation for itself and wearing out" (Book III, Ch. 15: 423). Now Carton, we might say, thinks in terms of the religious category of transfiguring rather than in terms of the historical category of transforming. In Buxi's speech the process is reversed. Mishra also differentiates this speech from Carton's interior monologue by rendering the former dialogically. The radicalism of this vision lies in its conception of the past as the pre-history of the present, with the present itself grasped as the seed-bed of the future.

The ending of Athara Sa Satara, unlike that of A Tale of Two Cities, tends to reinforce this proleptic gesture. The latter novel ends with the death of Carton, a martyr to the cause of love, and with his pre-death vision of rest. The former novel, however, does not stop short at the similarly contrived sacrificial death of Ghanashyama, but goes on to hand over the narrative to a prophetic voice singing an apocalyptic song - and songs constitute another bold new addition to Mishra's adaptive project - of a rejuvenated Orissa. No where in the novel is Mishra's touch finer and more subtle than in this last scene where Ghanashyama willingly accepts death by hanging. His touch here consists in humanizing the whole experience, as is shown in the text by Ghanashyama's crying out in fear and agony at the moment when the hangman's noose tightens around his neck: "Banamali, it hurts too much. Don't put your neck through the noose" (p. 661). The corresponding experience in Dickens is, by contrast, idealized, and is not treated on the physical, human plane. A very good example surely of translating against the grain. The song, though rooted in the doomsday poetic tradition of ancient Orissa, stemming from the Malikas, effects a secularization and radicalizing of its essentially religious content. The adaptive project of Mishra, focussed as it is on the achievable and realizable future, remains open ended.

The process of translation has rightly been defined as "a regulated transformation of an original text" (St-Pierre 1990:245). Surely this is best illustrated by the case of the Oriya adaptation/translation of Dickens's classic novel. The regulatedness of this enterprise is instanced by the elaborate system of equivalences between the two texts, while its 
transformative power is a product of a rewriting, managed by translating against the grain. So what seems to be happening in Athara Sa Satara is not a "naturalization" of the dominant, imperial text, but a process of emptying it out of its imperial assumptions with a view to filling it with a radical anti-colonial, nationalist content. The central act of rebellion, as Eric Cheyfitz has finely argued, is to "possess the master's books" (1991: 33) so as, we might add in closing, to make them sing an "insurrectionary tune." This is precisely what Athara Sa Satara has accomplished through its subversive translational strategies. To highlight such translational subversiveness, as has been attempted here, is to reverse our Eurocentric way of dealing or negotiating with texts, especially with "texts produced in cultures in contact." This dominant practice, as André Lefevere has shown, has consisted in a dual operation of shoring up the world view of the colonizer and of undermining that of the colonized. Such a power relationship has to be reversed or defeated. This would involve the dialectical positioning of texts produced in cultures in contact through colonization. This relativising operation is the special prerogative of translation in certain historical situations, as has here been shown through an analysis of Mishra's translation/adaptation of Dickens's classic.

\section{Notes}

1. It is interesting to note in this connection that the three other novels by Mishra, namely Nirbasita (The Banished), Abhagini (The Miserable) and Ghatantara (Out of the Body) also happen to be adaptations of well-known Western novels. Although not much light has been shed on the Western counterpart of Nirbasita, we know that Abhagini and Ghatantara are adapted from Les Misérables by Victor Hugo and The Strange Case of Dr. Jekyl and Mr. Hyde respectively. The case for Athara Sa Satara being an adaptation of A Tale of Two Cities may not have been made explicit, but the fact remains that any educated reader who reads the novel immediately sees the connection. The important point, of course, is this: although, unlike Radhanath Ray, Mishra was not drawing on multiple sources but was working on a text to text basis, he never felt his adaptive activity to be secondary or parasitical in nature, and, for that reason, did not feel obliged or constrained to acknowledge the fact of adaptation. It was also an expression of his cultural independence from the West. Surely Mishra's adaptive project as it is worked out in all his four novels calls for a more nuanced analysis, backed up by new approaches to translation. Our brief article is only meant to pave the way for. such an analysis.

2. It is true, as Tripathy observes in a fine article, that Radhanath Ray was able to create parallel texts in Oriya through the "diversification of source," coupled with the "Indianization" of situation (1987: 72). But to privilege such free renderings over translation or adaptation, as he goes on to do next by suggesting that the posing of multiple texts destroys the textual integrity or identity of the original material, is to beg the question. For it implies that when Tripathy talks about translation he invariably takes it to mean literal translation where a one-to-one correspondence between texts is proposed. This is not always true. As we have shown in our article, Mishra's adaptation of A Tale of Two Cities, even when it proposes a text to text transference, violates such textual integrity or identity by translating Dickens's novel against the grain.

\section{REFERENCES}

CHEYFITZ, Eric (1991): The Poetic of Imperialism: Translation and Colonization from The Tempest to Tarzan, New York/Oxford, Oxford University Press.

DICKENS, Charles (1859): A Tale of Two Cities. Herfordshire, Wordsworth Editions Limited, 1993.

GROSS, John (1962): "A Tale of Two Cities", Dickens and the Twentieth Century, John Gross \& Gabriel Pearson (Eds), London, Routledge and Kegan Paul, 1966, pp. 187-197.

JACQUEMOND, Richard (1992): "Translation and Cultural Hegemony: The Case of French-Arabic Translation", Rethinking Translation: Discourse, Subjectivity, Ideology, Lawrence Venuti (Ed.), London, Routledge, pp. 139-158.

LEFEVERE, André (1988): Essays in Comparative Literature, Calcutta, Papyrus.

MISHRA, Godavarish (1989): Athara Sa Satara, Godavarish Granthabali, Raghunath Mishra (Ed.), Cuttack, Cuttack Students Store.

SAID, Edward W. (1993): Culture and Imperialism, London, Chatto and Windus.

SANDERS, Andrew (1978): The Victorian Historical Novel, London, Macmillan. 
ST-PIERRE, Paul (1990): “Translation: The Need for an Historical Approach", Translation in Canada: Achievements and Challenges: Proceedings of the 2 nd Conference of the Canadian Translators and Interpreters Council, pp. 245-254.

TRIPATHY, Biyot Kesh (1987): "The West and the Renaissance in Oriya Literature", Jadavpur Journal of Comparative Literature, 25 , pp. 60-75.

TRIVEDI, Harish (1993): Colonial Transactions: English Literature and India, Calcutta, Papyrus.

VISWANATHA, Vanamala and Sherry SIMON (1996): "A Relative of the Original", The Hindu Magazine, Sunday, August 18, p. xii, p. xvi.

VISWANATHAN, Gauri (1989): Masks of Conquest: Literary Study and British Rule in India, London, Faber \& Faber. 